\title{
RESEARCH OF THE PHYSICAL DEVELOPMENT OF BASKETBALL STUDENTS FROM SOFIA UNIVERSITY ST. "KLIMENT OHRIDSKI"
}

\author{
I. Peltekova* \\ Department of Sport, Sofia University, St. Kliment Ohridski”, Sofia, Bulgaria
}

\begin{abstract}
The article presents the results of the measurements made on the physical development of students who have chosen basketball as a compulsory discipline. The measurements include height, weight, and body mass index (BMI). All participants in the study are students from Sofia University, a regular form of education. Students are in age between 18 and 26, from different faculties and disciplines. The results are based on gender and age. Two measurements were made-Test 1 and Test 2 (T1 and T2). According to the results of BMI, the students are divided into four categories: "healthy range", "lower than healthy", "overweight" and "obesity".

According to the results obtained in BMI calculation, it was found that in T1 for women and men 66.2 $\%$ of the students were in a "healthy range", ranked on the index of obesity. In T2 the percentage increased to $68.8 \%$. $14.3 \%$ of the students have "lower than healthy" weight. For women this percentage is higher- $18.2 \%$ compared to men $11.4 \%$.
\end{abstract}

Key words: study groups, motor activity, sport, body mass, health

\section{INTRODUCTION}

The physical education and sport in the universities and in particular the basketball practice can help maintain good physical condition, strengthen and preserve health, build personal qualities and improve the effectiveness of learners' actions, while the body and the personality of the players to develop in harmony.

The high educational and healing value of the basketball provides a victorious procession all over the world. Basketball is practiced in schools, universities, and sports clubs. It is covered in all areas of sports activities and applies in various forms. The formation of active personalities is an important condition in preparing the students for the building of harmonious and acquiring the necessary knowledge and skills for their future professional and social activity after university graduation.

\footnotetext{
*Correspondence to: Iren Peltekova, PhD; Department of sport, Team sports and mountain sports, Sofia University, address: bul. "Tsar Osvoboditel” 15, 1504 Sofia, Bulgaria, email:iren.peltekova@gmail.com, telephone: $+359 / 887511468$
}

The large amount of information and the increase workload in the education results in accumulation for students to reduce the negative psycho-physical processes and improve their health condition is to practice sports (1).

The motor activity is an invariable naturalbiological need of the person without whom his life is impossible. It has been found that in immobilization in the human body there are a number of negative changes related to atrophy and reduction of the function of almost all organs and systems.

The physical adequacy of students can be improved by optimizing and introducing innovative methods, circular exercises and various sport-pedagogical approaches in physical education and sports classes (2-3). This is the focus of the efforts of the sports pedagogues of Thracian University, which thorough examine the physio metric indicators of students (4-5).

The everyday life of modern people, especially those with small and medium income is characterized by low physical activity. People with low physical activity more often suffer 
from obesity, putting them at risk of heart attack, stroke, type 2 diabetes mellitus, hypertension, gallstones and other diseases.

According to the World Health Oganisation (WHO), the body weight of a person is classified into several healthy limits. Obesity and its opposite to malnutrition are problems that affect more and more young people. A survey by Hristova P. (2016) found that 32.3\% of 90 female students studying at Sofia University "St. Kliment Ohridski" participating in the aerobics classes are underweight and $6.66 \%$ are overweight. The remaining $61.13 \%$ have normal body weight (6). In calculating the BMI of students from the Thracian University it is found that $34.33 \%$ of students are overweight, $59.70 \%$ are underweight, $5.97 \%$ are with normal weight.

The difference between chest circumference at rest and exhale is $2 \mathrm{~cm}$, which indicates relatively good development of the chest and good state of the respiratory system, but it is indicative that the students did not lead a physically active way of life, did not sport and performed regular aerobic exercise. The mean difference between inhalation and exhalation of students is $4.97+1.30 \mathrm{~cm}$, which is significantly less than the average for women $(6.9+-2.6 \mathrm{~cm})(7)$.

Ignatov G., Mladenov L. (2013) conducted a series of studies related to the somatotype and physical development of students (men and women) practicing football in universities. The results show that female students have normal BMI, low body fat and well developed muscle mass (8). Similar are the data also for students from the male football team of Sofia University "St. Kliment Ohridski" who found that the anthropometric characteristics and their somatotype are comparable to the published data for the players (9). The tracked dynamics in the development of the same anthropometric performance of students training football after applying a specialized training model found that after purposeful work, better results could be achieved (10).

The health should be a personal responsibility of every person and young people know this. Some conclusions were made in the study of Kyuchkova S. (2018): where is written: „Students with medical specialties have learned and realized that health is not a constant magnitude. They take it as a dynamic equilibrium, which, in order to maintain, requires constant and conscious efforts. At the same time, they are clearly aware of the fact that the lack of disease and the affluent lifestyle are not a measure of good health. The physically healthy person, who is devastating in his actions towards himself and others, is deeply ill in his nature. That is why, the responsibility for their own health, HMU students take with care and professionalism. For them, health is not only the absence of illness or disability, but is an expression of the way of thinking and the content of life" (11).

Physical development is really important to the basketball players. The basic characteristics of the basketball game play positions are the physical development and the acquired technical skills of the athletes. That is why we set ourselves the following goal:

Objective: To study to the parameters of the physical development of the students from the basketball groups.

\section{METODOLOGY}

Methods: The growth and weight metrics were measured, BMI was calculated. An experimental methodology for the basketball training in the university has been approved. Weight and level of obesity were tracked during the experiment input-output. Height was measured only at the beginning of the study. Specimen analysis (ANOVA) and variation analysis, mathematical and statistical processing of the results SPSS version 19.

Respondents: 77 Students of Sofia University, a regular form of education from different faculties and majors. All students have the discipline "Sports" in the school curriculum and they have chosen to practice basketball. Students are divided into four groups - two experimental and two controllers in the following way: E1 - male (23 students), which is $29.9 \%$; E2 - women (16 students), which is $20.80 \%$, K1 - men (21 students), which is $27.3 \%$ and $\mathrm{K} 2$ - women (17 students), which is $22.10 \%$.

\section{ANALYSIS OF THE RESULTS}

The researched students are in age between 18 - 26 years. The mean age of the groups is: $\mathrm{E} 1=19.78$, E2=19.43, K1=20,14, K2=19.94.

Height, weight, BMI of the students in the basketball group.

The presented data (Table 1) for the average height of the students from the basketball groups $(\mathrm{E} 2 / \mathrm{K} 2)$ is 169.55 , for men $(\mathrm{E} 1 / \mathrm{K} 1)$ the average height is $182.52 \mathrm{~cm}$. The women's weight at the entry level is $62.30 \mathrm{~kg}$ and the 
initial measurement is $61.15 \mathrm{~kg}$. There is a difference of $1.15 \mathrm{~kg}$ in the second measurement. For males the weight of the first measurement is $78.59 \mathrm{~kg}$ and the second one is $78.45 \mathrm{~kg}$. There is no statistically significant difference in kilograms between the first and second measurement. The table shows that men have higher growth and weight ratios than women. The results show that men on average are $12.97 \mathrm{~cm}$ taller and $6.8 \mathrm{~kg}$ heavier than women.

Table 1. Average value of the first and second measurement of the weight and BMI

\begin{tabular}{|c|l|l|c|c|}
\hline Indicator & Gender & Mean & $\mathrm{n}$ & S.D. \\
\hline \multirow{2}{*}{ Height } & Women & $169,55 \mathrm{~cm}$ & 33 & 6,88 \\
\cline { 2 - 5 } & Men & $182,52 \mathrm{~cm}$ & 44 & 6,11 \\
\hline \multirow{2}{*}{ T1 - Weight } & Women & $62,30 \mathrm{~kg}$ & 33 & 8,99 \\
\cline { 2 - 5 } & Men & $78,59 \mathrm{~kg}$ & 44 & 9,90 \\
\hline \multirow{2}{*}{ T2 - Weight } & Women & $61,15 \mathrm{~kg}$ & 33 & 8,51 \\
\cline { 2 - 5 } & Men & $78,45 \mathrm{~kg}$ & 44 & 9,02 \\
\hline \multirow{2}{*}{ T1 - BMI } & Women & 21,56 & 33 & 2,90 \\
\cline { 2 - 5 } & Men & 23,70 & 44 & 3,68 \\
\hline \multirow{2}{*}{ T2 - BMI } & Women & 21,21 & 33 & 2,70 \\
\cline { 2 - 5 } & Men & 23,61 & 44 & 3,31 \\
\hline
\end{tabular}

The results of the dispersion analysis (ANOVA) for the influence between the growth factors and sex factors showed a statistically significant relationship $(\mathrm{F}=72.262$, $\mathrm{p}=0.000$ ). For both weight and sex, there is also a significant association with both the first indicators $(\mathrm{F}=55.115, \mathrm{p}=0.000)$ and second $(\mathrm{F}=72.790, \mathrm{p}=0.000)$. In BMI and sex the relationship is weaker but statistically significant $(\mathrm{F}=7.465, \mathrm{p}=0.008)$ and $(\mathrm{F}=11.612$, $\mathrm{p}=0.001$ ). (Table 2).

Table 2. ANOVA summary for Height, Weight, Gender and BMI

\begin{tabular}{|c|c|c|c|c|c|c|}
\hline Combined & Groups & $\begin{array}{l}\text { Sum of } \\
\text { Squares }\end{array}$ & $\mathrm{df}$ & Mean Square & $\mathrm{F}$ & Sig. \\
\hline \multirow{2}{*}{ Height $*$ Gender } & $\begin{array}{c}\text { Between } \\
\text { Groups }\end{array}$ & $3,175,724$ & 1 & $3,175,724$ & 76,262 &, 000 \\
\hline & $\begin{array}{l}\text { Within } \\
\text { Groups }\end{array}$ & $3,123,159$ & 75 & 41,642 & & \\
\hline \multirow{2}{*}{ T1-Weight $*$ Gender } & $\begin{array}{c}\text { Between } \\
\text { Groups }\end{array}$ & $5,002,706$ & 1 & $5,002,706$ & 55,115 & ,000 \\
\hline & $\begin{array}{l}\text { Within } \\
\text { Groups }\end{array}$ & $6,807,606$ & 75 & 90,768 & & \\
\hline \multirow{2}{*}{$2 \mathrm{~T}$-Weight $*$ Gender } & $\begin{array}{c}\text { Between } \\
\text { Groups }\end{array}$ & $5,645,732$ & 1 & $5,645,732$ & 72,790 &, 000 \\
\hline & $\begin{array}{l}\text { Within } \\
\text { Groups }\end{array}$ & $5,817,152$ & 75 & 77,562 & & \\
\hline \multirow{2}{*}{ T1-BMI * Gender } & $\begin{array}{c}\text { Between } \\
\text { Groups }\end{array}$ & 84,546 & 1 & 84,546 & 7,465 & ,008 \\
\hline & $\begin{array}{l}\text { Within } \\
\text { Groups }\end{array}$ & 849,412 & 75 & 11,325 & & \\
\hline \multirow{2}{*}{ T2-BMI * Gender } & $\begin{array}{c}\text { Between } \\
\text { Groups }\end{array}$ & 108,823 & 1 & 108,823 & 11,612 & ,001 \\
\hline & $\begin{array}{l}\text { Within } \\
\text { Groups }\end{array}$ & 702,892 & 75 & 9,372 & & \\
\hline
\end{tabular}


According to the results obtained in the BMI calculation, $66,1 \%$ of students in the $\mathrm{T} 1$ in women and men are found in a "healthy range" classifies by the obesity index. At T2, this percentage increased to $68.8 \%$. $14.3 \%$ of the students on the first measurement have a weight "lower than the normal", while for women this percentage is higher-18.2\% and for the men is $11.4 \%$ (Table 3)

Table 3. BMI-Chart \%

\begin{tabular}{|c|c|c|c|c|}
\hline \multirow{3}{*}{ Indicator } & \multirow{3}{*}{ BMI CHART } & \multicolumn{3}{|c|}{ Gender } \\
\hline & & Women & Men & $\mathrm{W} / \mathrm{M}$ \\
\hline & & $(\mathrm{n} / \%)$ & $(\mathrm{n} / \%)$ & $(\mathrm{n} / \%)$ \\
\hline \multirow{8}{*}{ T1 - BMI } & \multirow{2}{*}{ Underweight } & 6 & 5 & 11 \\
\hline & & $18,2 \%$ & $11,4 \%$ & $14,3 \%$ \\
\hline & \multirow{2}{*}{$\begin{array}{l}\text { Healthly } \\
\text { Weight }\end{array}$} & 23 & 28 & 51 \\
\hline & & $69,7 \%$ & $63,6 \%$ & $66,2 \%$ \\
\hline & \multirow{2}{*}{ Overweight } & 4 & 8 & 12 \\
\hline & & $12,1 \%$ & $18,2 \%$ & $15,6 \%$ \\
\hline & \multirow{2}{*}{ Obese } & - & 3 & 3 \\
\hline & & $0 \%$ & $6,8 \%$ & $3,9 \%$ \\
\hline \multirow{8}{*}{ T2 - BMI } & \multirow{2}{*}{ Underweight } & 8 & 4 & 12 \\
\hline & & $24,2 \%$ & $9,1 \%$ & $15,6 \%$ \\
\hline & \multirow{2}{*}{$\begin{array}{l}\text { Healthly } \\
\text { Weight }\end{array}$} & 22 & 31 & 53 \\
\hline & & $66,7 \%$ & $70,5 \%$ & $68,8 \%$ \\
\hline & \multirow{2}{*}{ Overweight } & 3 & 8 & 11 \\
\hline & & $9,1 \%$ & $18,2 \%$ & $14,3 \%$ \\
\hline & \multirow{2}{*}{ Obese } & - & 1 & 1 \\
\hline & & $0 \%$ & $2,3 \%$ & $1,3 \%$ \\
\hline
\end{tabular}

In the $\mathrm{T} 2$ stud for the same indicator there was a change in the percentage of women in the "lower than normal" weight range $(24.4 \%)$ and in men the rate decreased to $9.1 \%$. The remaining students are in a "overweight" range for women $\mathrm{T} 1-12.1 \%$ and $\mathrm{T} 2-9.1 \%$ and male $18.2 \%$ with no change during the study period.

\section{CONCLUSION}

The male students of the basketball groups have a mean age 19.96 years, with mean height $182.52 \mathrm{~cm}$ and body mass $78.52 \mathrm{~kg}$, which determines BMI of 23.6

The female students of the basketball groups have a mean age 19.96 years, with mean height $169.95 \mathrm{~cm}$ and body mass $61.72 \mathrm{~kg}$, which determines BMI of 21.1

The results show that men are higher with $12.97 \mathrm{~cm}$ and heavier with $16.8 \mathrm{~kg}$ compared to women.

In conclusion it can be said that the bigger percentage of the students from basketball learning sports groups from Sofia University "St. Kliment Ohridski", are classified by BMI, the healthy range $68.2 \%$ for women and $67.05 \%$ for men.

Students with weight "lower than the normal" are $21.2 \%$-women and $10.25 \%$-men. Students with "overweight" are $10.6 \%$ - women and $18.2 \%$-men. In the group "obesity" there is no registered women, and men are $4.55 \%$.

The motor activity provided by physical exercise and sports can increase health condition and speed up the recovery after the accumulation of fatigue in young people.

\section{REFERENCES}

1. Prokopov, E. and Yaneva, A., Sportseducational practices for the Students of Sofia University. Yearbook of Sofia University, "St. Kliment Ohridski " - press, S., ISSN 0205-0692, vol. 85, pp. 23 - 30, 2009.

2. Petkov P., Influence of round exercises on the composition of the body mass of students, NC "Challenges and Prospects before Sports Science", NSA, S., ISBN 978-954-718-492-3, pp. 211-219, 2017. 
3. Dyakova, G. and Petkov P., Comparing Physical Fitness Indicators in Students", Collection of Reports, "Pedagogical Education - Traditions and Modernity", VTU, 20 - 21 November, ISBN 978-6197281- 01-9, 2015.

4. Dyakova, G., Textbook on physical education and sport. Tr. U - press, ISBN 978-954-338-046-6, p.120, 2013.

5. Petkov. P. and Angelova. P., Examination of physiometric indicators in students. Sessions schedule\&Abstracts, 2018 - Ruse, Razgrad, Silistra, FRI-2G.104-1-HC-06, pp $270-271,2018$.

6. Hristova, P. Analysis of the Body Mass Index of female university students enlisted for aerobics classes. "Modern Trends in Physical Education and Sport", Sofia, ISSN 1314-2275, vol. 8, pp. 105-109, 2016.

7. Peltekova, I. and Petkov, P., Determination of the level of physical development of female students from physical education sport groups in Trakia university. Sport \& Science Magazine, S., № 2, ISSN 13103393, pp.161-169, 2017.

8. Ignatov, G. and Mladenov, L., Analysis of the somatotype and composition of the body mass of the women's football team of Sofia University "St. Kliment Ohridski ".
PELTEKOVA I.

ISSN 1310-3393, Sports \& Science № 4, pp. 32-40, 2013.

9. Ignatov, G. And Mladenov, L. Examination of the somatotype and composition of the body weight of the male football team of Sofia University "St. Kliment Ohridski ". ISSN 1310-3393, Sports \& Science Magazine №1, pp. 51-56, 2013.

10.Georgiev, A. and Ignatov, G. Tracking the changes in the anthropometric performance of female students following an applied model for training women's football in higher schools. Tenth International Scientific Conference. Department of Sports. SU "St. Kliment Ohridski ", 09. XI. 2018. Reports "Modern Trends in Physical Education and Sports". University Publishing House "St. Kliment Ohridski ". ISSN 1314-2275, pp. 28-38, 2018.

11. Kyuchukova, S. The responsibility of the students with medical specialties for their own health - reality and opportunities for prevention. Copyright (C) 2018 Trakia University Available online at: http: /www.uni-sz.bg. ISSN 1313-3551 (online) doi: 10.15547/tjs.2018. s. 01.005 .

Trakia Journal of Sciences, Vol. 16, Suppl. 1, pp 24-28, 2018. 